\title{
LUKE'S VIEW ON POVERTY IN ITS ANCIENT (ROMAN) ECONOMIC CONTEXT: A CHALLENGE FOR TODAY
}

\author{
Eben Scheffler \\ Department of Old Testament \\ University of South Africa
}

\begin{abstract}
After a brief sketch of the diversity of perspectives on poverty in literary corpuses of the Bible, attention is paid to the Roman economic context as backdrop for Luke's view on poverty. This is followed by focusing on Luke's view on poverty within this context, scrutinising the term 'ptochos' (poor), his attitude towards the rich (or relatively) wealthy and his view on renunciation of possessions and charity. After a brief look at some receptions or appropriations of Luke's view throughout history (e.g. individual charity, monastic life, Marxism and liberation theology) some (preliminary) hermeneutical conclusions regarding the need for present-day poverty eradication are drawn.
\end{abstract}

Key words: Gospel of Luke, Poverty, Ancient Roman Economy

\section{Introduction: Diverse Views on Poverty in the Bible}

As is the case regarding most human problems, there exists a kaleidoscopic diversity of views on poverty in the Bible. A quick glance at the various corpuses of literature provides a preliminary insight into this diversity, putting the Gospel of Luke's particular view into relief.

- In the Tanach several Mosaic laws, ${ }^{1}$ as they find expression in the Covenant- (Ex 21:1-11; 22:21-24; 22:25; 22:25-27; 23:2,6; 23:1), Holiness- (Lev 19:10; $19: 13,15 ; 25)$ and Deuterenomic Codes (especially Deut 15:1-18), prescribe how the poor should be positively treated (Berges 2000:227-250). The Pentateuch does not present these laws as having a universal or inclusive applicability, but rather as meant to be obeyed within the context of Israel itself, who is conceptualised as a family (cf. the term $\pi$ [w] 'brother'] in Dt 15:2; see Braulik 1986; Scheffler 2005; 2010).

- The Deuteronomistic history contains the story of Naboth's vineyard (1 Ki 21:1 -9), where the exploiting king is prophetically criticised and challenged (see Bosman et al 1991; Farisani 2005). ${ }^{2}$

- The Chronicler presents a more positive view on the involvement of governing powers: Nehemiah 5's report by Nehemiah narrates the virtuous behaviour where the ruler of the day sacrificed his own rights in order to address the poverty situation in the country (cf. Ps 72:1-4, 12-14; see Gunneweg 1987:90-93; Rudolph 1949:131-133; Usue 2010). 
- A diversity of views is also to be found in about 50 of the 150 Psalms (Lohfink 1992-1994), of which the so-called 'piety of the poor' (Armenfrömmigkeit, cf. Rahlfs 1892; Kraus 1979:188-193; Groenewald 2003:147-153; Scheffler 2011:197-198) is but one. ${ }^{3}$

- Even within wisdom literature the diversity continues. Whereas the book of Proverbs (cf. also Jesus Sirach) generally advocates a charitable attitude towards the poor, the poor on the other hand are also reprimanded for being responsible for their own situation by being lazy, depending on the situation. Different from the conventional wisdom of the book of Proverbs, the critical wisdom of Job and Qohelet wrestles with the poverty in terms of the theodice problem (see Spangenberg 2010:101-120).

- In the prophetic literature (especially Amos and Micah) the rich, as well as the political and religious leaders are heavily criticised for exploiting and not caring for the poor, each book having its own unique emphasis as the contexts demanded (see Van Heerden 1991; 2010).

- In the New Testament the emphasis on poverty can be traced back to the historical Jesus who according to the oldest witnesses was poor himself (QLk 9:58), but pronounced the poor blessed (QLk 6:20-21; Mt 5:3), preached for them (QLk $7: 22$ ), cared for them through the multiplication of the bread and gave his disciples the responsibility to care for them (Mk 6:36; QLk 12:33; Mk 10:21; Lk $16: 19: 31)^{4}$

- The earliest New Testament writings, although not as radically as Jesus, continued to reflect this positive attitude. Paul pursued (besides being an apostle) his own profession as tent-maker in order to be materially independent and having something to give to the poor. He was also involved in organising the collection of money amongst the Asian churches for the poor church in Jerusalem (2 Cor 8-9; see Joubert 2000).

- Especially the letter of James (probably written between 50-60 CE), while emphasising correct ethical behaviour as a fruit of genuine faith (cf. Js 1:22), championed for the poor by reprimanding rich members of the congregations who discriminated against poor people (cf. Js $1: 9-10,27 ; 2: 3,16$ ).

- The writing of the synoptic Gospels in the eighties of the first century can be regarded (amongst others) as an attempt to preserve Jesus' own teaching in view of the contemporary Christian teaching about him. The Gospels thus reflects Jesus' caring for the poor, although each in its own different way. Although Mt 5:3 ('Blessed are the poor in spirit', contra Lk 6:20) seems to suggest that Matthew spiritualises the concept of 'the poor', such a conclusion cannot be drawn for the Gospel as a whole (cf. Mt 11:5; 19:21; 25:25-46). In Mark's Gospel Jesus is portrayed as having a house (together with his disciples, cf. 2:1,15, contra Lk 5:29) and advocating a stance that concern for the poor should not override other expressions of love and compassion (cf. his version of the women's

\footnotetext{
For a brief overview of this diversity, see Scheffler 2011:194-198: In the psalms the king should care for the poor (e.g. Ps 72), God cares for the poor (Ps 9), God and the gods care for the poor (Ps 82), a descendant of David will care for the poor (Ps 32), God crushes the poor (Ps 88) ordinary people should care for the poor (Ps 41) and the concept of the poor is used in a metaphoric (cf. Armenfrömmigkeit) sense (Ps 109).

4 For a brief summary of Jesus' stance on caring for the poor see Scheffler 2009:225-227. cf. also the more detailed and comprehensive treatment by Jeremias 1971:110-123.
} 
anointment in Mk 14:3-9, contra Lk 7:36-60). In Mark's two versions of the feeding of the crowd (Mk 6:30-44 and 8:1-21), where the feeding can be interpreted in eucharistic terminology (Mk 6:41; 8:6-7), the conclusion can also not be drawn that Mark spiritualises the concept in the sense of abolishing its literal meaning. The command to the disciples to care for the poor ('Give you them something to eat') is pivotal in the episode (Mk 6:37). For Mark caring for the literal poor remains a continuing responsibility $(14: 7){ }^{5}$

- In Luke's Gospel the theme of caring for the poor is extensively elaborated upon ('amplifying' Jesus' view as it were) and many more references to the poor are included in his Gospel as the situation of his community (which consisted of rich and poor Christians) demanded (cf. amongst others Lk 4:18-19; 6:20; 7:22; 11:39;12:33: 14:13,21; 16:20,22; 18:22; 21:3). In what follows, Luke's view will be focused upon within its ancient (Roman) economic context. His double volume (Luke-Acts) does not only constitute the largest (and often neglected) literary corpus in the New Testament, but is also the biblical writing that deals most extensively with the issue of poverty. Moreover this concern for the poor is also interconnected with other aspects of human dignity and suffering, for example physical and mental illness, social ostracism (women, children, despised professions) and political enmity (see Guthrie 1970:90-92; Scheffler 1993:61-102; Scheffler 2006:90-103).

According to Schnelle (2007a:287) an increasing number of scholars surmise that LukeActs was probably written in Rome, since Luke ' 'looks from west to east'. Of course Palestine was part and parcel of the Roman Empire, but looking at the Gospel and Acts with the Roman capital in mind (cf. e.g. Acts $1: 8 ; 28 ; 16-17$ ), promises to illuminate Lucan thought to a great extent. Below brief attention will therefore first be paid to the ancient Roman economic context that would serve as a backdrop for Luke's views on poverty (par 2), followed by focusing on Luke's view on poverty within this context (par 3). After a brief look at some receptions or appropriations of Luke's view throughout history, some (preliminary) hermeneutical conclusions will be made.

\section{The Roman Economic Context as Backdrop for Luke's View}

It should be noted at the outset that reconstructing the economic context against which Luke's Gospel could be read is a daunting task. The following remarks are therefore preliminary and only provide some broad guidelines of aspects that could be considered.

First of all the ancient (Roman) economic context should not be regarded as having been homogenous. Although the Romans dominated the inhabited world, they simply did

\footnotetext{
The misinterpretation and misappropriation of Jesus' remark in Mk 14: 7 ('you will have the poor always among you') which often occurs when people in a despondent fashion wish to shy away from their responsibility to care for the poor, warrants some comment. In Mk 14:7 Jesus quotes from Dt 15:11 (cf. Mt

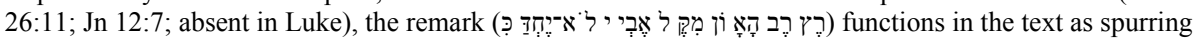
them on to alleviate poverty (cf. 11b: 'so I command you to be generous to them') and not as a despondent pronouncement that should have a detrimental effect on efforts to eradicate poverty. The same can be concluded with regard to Jesus' use of it. Perhaps the greatest obstacle in the endeavour to eradicate poverty is the myth that it is impossible to put an end to it. This myth is in urgent need to be dispelled, as argued by Sachs (2005:34).

6 For convenience the name "Luke" is employed to refer to the author of the Gospel and Acts, not implying anything about his identity as the physician and friend of Paul (cf. Col 4:14). On the basis of the eyewitness character of the "we narratives" in Acts (especially Acts 28), I am of the opinion that the same person authored the Gospel and Acts and that he accompanied Paul to Rome.
} 
not have the means to enforce economic policies that could be uniformly applied throughout the Empire. It is therefore simplistic to distinguish a policy that was in operation at a specific time and place and then to 'transfer' that policy to the ancient world or Empire as a whole.

According to Schmithals (1975:163-166; 1985) Luke's emphasis on the poor can be understood in terms of the persecutions under Emperor Titus Flavius Domitianus (Domitian) who reigned from 81-96 CE. ${ }^{7}$ As far as Christians were concerned these persecutions (which could in some cases lead to death) were primarily of an economic nature: financial punishment (Geldstrafe) and confiscation of property. ${ }^{8}$ Constable (2003:117) notes that Domitian (suffering from paranoia and trying to rid himself of potential rivals) needed the money due to expensive military campaigns in Germany, lavish spending on buildings (e.g. his massive palace on the Palatine hill, cf. Claridge 2010:145-159) and a substantial pay rise to legionaries to ensure their loyalty. The economic policies of Domitian were therefore context-related and the contingent circumstances under his reign should not be regarded as prevalent in other situations of the Roman Empire.

Secondly the question should be asked against which specific context (Rome, Palestine or both) Luke-Acts should be read. Should the Gospel be read against a Palestinian background and Acts against a broader Roman background? As a first century historian Luke succeeded remarkably well in creating a distance between his own time and the narrated world of his Gospel. Luke was fully aware that Palestine was part of the Roman Empire (cf. his explicit reference to Augustus and the Roman world in Lk 2:1), but he situated his Jesus story squarely within the context of Palestine (Lk 2:4). Should economic conditions in Palestine (so aptly described by Jeremias in his Jerusalem zur Zeit Jesu (1974) be regarded as the main backdrop of his story, or should it be the broader Roman Empire?

In considering these questions Bauckham's view that Luke meant his work not primarily for a specific context (nor Palestine, nor Rome) but for the whole world, also comes into play. Luke evidently reflects an inclusive attitude: Not only will many from the east and west take their place in the kingdom, but he added (contra his source, cf. QMt 8:11) the words 'north' and 'south', thereby emphasising his universalism (Lk 13:29). The vision in Luke 24:4 and Acts 1:8 is clear: the gospel will be preached "in Jerusalem, and in all Judea and Samaria, and to the ends of the earth". 9

To my mind Bauckham's view of Luke's universal vision should be conceded (cf. Scheffler 1993:81-83), without underplaying the context-related circumstances in which his writings originated and were addressed (Scheffler 2006:78-82). It also stands to reason that if he wrote his Gospel in Rome, the contingent prevailing circumstances would have influenced him, even if only on a subconscious level. To investigate the prevailing Roman economic context during the time of his writing is therefore fully justified.

Our third consideration relates to the hierarchy in contemporary Roman society. To my mind an analysis in which only two main classes, rich and poor, or patrons and

\footnotetext{
Most New Testament scholars date Luke's Gospel during this period.

That Domitian probably did not kill Christians on a large scale (cf. Botha 1988:98) can be explained by the fact that the Roman Christians at this stage were a minority group not posing a real threat to his power.

9 The expression "ends of the earth" should therefore according to Bauckamm be read in its literal sense and not as the "end of the then known earth" which would imply the Roman Empire.
} 
clients, are distinguished, is too simplistic. Any society in the first century consisting of about 500,000 to a million people (surely would have been more complex.

Various scholars are in agreement that several economic classes existed in Rome (e.g. Whittaker 1993; Friesen 2004; Scheidel 2006; Longenecker 2009). Friesen (2004) distinguished seven economic classes which are presented in the following table:

\begin{tabular}{|c|c|c|}
\hline $\begin{array}{c}\text { ECONOMIC } \\
\text { CLASS } \\
\end{array}$ & CLASS DESCRIPTION & PERCENTAGE \\
\hline (1) Imperial elites & $\begin{array}{l}\text { The imperial dynasty, Roman senatorial } \\
\text { families, a few retainers, local royalty, } \\
\text { few freed persons }\end{array}$ & $0,04 \%$ \\
\hline $\begin{array}{l}\text { (2) Regional or } \\
\text { provincial elites }\end{array}$ & $\begin{array}{l}\text { Equestrian families, provincial officials, } \\
\text { some Retainers, some decurial families, } \\
\text { some freed-persons, some retired military } \\
\text { officers. }\end{array}$ & $1 \%$ \\
\hline (3) Municipal elites & $\begin{array}{l}\text { Most decurial families, wealthy men and } \\
\text { women who do not hold office, some } \\
\text { freed persons, some retainers, some } \\
\text { veterans, some merchants }\end{array}$ & $1.76 \%$ \\
\hline $\begin{array}{l}\text { (4) Moderate surplus } \\
\text { resources }\end{array}$ & $\begin{array}{l}\text { Some merchants, some traders, some } \\
\text { freed persons, some artisans (especially } \\
\text { those who employ others), military } \\
\text { veterans }\end{array}$ & $7 \% ?$ \\
\hline $\begin{array}{l}\text { (5) Stable near sub- } \\
\text { sistence level }^{10} \\
\text { (with hope of } \\
\text { remaining above } \\
\text { the minimal level) }\end{array}$ & $\begin{array}{l}\text { Many merchants and traders, regular wage } \\
\text { earners artisans, large shop owners, freed } \\
\text { persons, some farm families }\end{array}$ & $22 \%$ \\
\hline $\begin{array}{l}\text { (6) At subsistence } \\
\text { level (and often } \\
\text { below minimum } \\
\text { level to sustain } \\
\text { life) }\end{array}$ & $\begin{array}{l}\text { Small farm families, labourers (skilled } \\
\text { and unskilled), artisans (especially those } \\
\text { employed by others), wage earners, most } \\
\text { merchants and traders, } \\
\text { small shop or tavern owners }\end{array}$ & $40 \%$ \\
\hline $\begin{array}{l}\text { (7) Below sub- } \\
\text { sistence level }\end{array}$ & $\begin{array}{l}\text { Some farm families, unattached widows, } \\
\text { orphans, beggars, disabled, unskilled day } \\
\text { labourers, prisoners }\end{array}$ & $28 \%$ \\
\hline
\end{tabular}

Some variations exist among the different authors, especially with regard to the extent of the lower categories (5-7) which in any case constitutes more than $80 \%$ of the population. Only a small percentage (about $3 \%$ ) of the population could be regarded as wealthy, $25 \%$ were starving with another $40 \%$ nearly starving. Slaves probably fell in the sixth category. They were also poor, but were kept alive because of their use, with the result that starvation was less likely.

Many people were small farmers (category 5-6) who owned property on a small scale, did some trading and paid taxes to the government. They constituted (together with

10 Friesen (2004:343) defines "subsistence level" as "the resources needed to procure enough calories in food to maintain the human body'. 
other small traders) the plebeians, and although not extremely poor, they were clearly at the lower end of the economical scale. Nevertheless these plebeians (over $50 \%$ of the population) were the 'economic middle' (cf. Longenecker 2009) who had some economic rights for which they advocated and which were already around $450 \mathrm{BCE}$ publicly displayed as the so-called Twelve-Table-Laws in the Forum in Rome (Bourmer, Reincker \& Strüber 2002:22). According the Constable (2003:128) a relatively wealthy merchant class (category 4) emerged in the first century and with the introduction of a stable currency (gold, silver and copper coins were minted) money was easier recycled, stimulating trade. Professions sharing in this relative wealth were (amongst others) plumbers, blacksmiths, carpenters, wheelwrights, spinners, dyers, bootmakers, buttonmakers and architects (Constable 2003:128). These relatively wealthy people (approximately about $10 \%$ of the population) were to a certain extent in a pact with the Caesar and filled the stands in the arenas and circuses when gladiators or chariot races entertained the Emperor. Panem et circenses ('bread and games') meant that there was a considerable number of people who, despite their struggle for survival, had at least enough to eat and drink. It is hard to imagine a Rome with all its architectonic splendour without such a layer of the community. ${ }^{11}$

Against this backdrop we can, in the fourth place, ask the question to which layer the $\pi \tau \omega \chi 0$ oi ('the poor') of Luke's Gospel belonged and to which layers of the economic

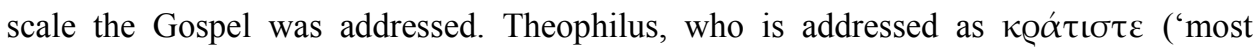
excellent') in Luke 1:4, was most likely not a poor person, but did he represent the top $3 \%$ of the superrich? The parable of Lazarus and the rich man functions in Luke 16 within the context of Jesus addressing the Pharisees who loved money (16:13-14), implying that they were rich, whereas we know that in actual fact the Pharisees came from the poorer layers of Palestine society. With further regard to the first century Palestinian context, Jeremias (1974) also distinguished the so-called 'noble laity' of relatively poor people who could occupy Sanhedrin membership.

In what follows I argue that Luke had the 'poorest of the poor' in mind (in other words the bottom $25 \%$ of the economic scale) when he wrote his Gospel in Rome and that it was his intention to mobilise all the other economic layers of society (even those who merely survived) to cater for the dying or 'begging' poor. In depicting his consistent focus on poverty his use of the term ptochos (poor) will firstly be scrutinised, followed by remarks on his use of his sources, his attitude towards the rich (or relatively) wealthy and his view on renunciation of possessions and charity.

\section{Luke's View of the Poor in its Literary and Economic Context}

\section{Luke's Use of the Term $\pi \tau \omega x \mathrm{x}$ ('the Poor')}

In his gospel Luke uses the term $\pi \tau \omega \chi 0 \varsigma 10$ times (out of 34 occurrences in the New Testament). The term penes (denoting moderate poverty) is never used. ${ }^{12}$ When Luke

11 In all probability the building of the massive Colosseum by Vespasian (69-79 CE) was facilitated by the relative upswing in the economy (cf. Calridge 2010:312-319; Quennell 1971).

12 In the New Testament four terms are used to refer to poverty. Besides ptochos the term penes refers to a person who is poor and must live sparingly and can merely survive, but not so extremely poor as a ptochos. It is used only once in the New Testament in 2 Corinthians 9:9. The term endees occurs also only once in the New Testament when it is stated in Acts 4:34 that no one in the early Jerusalem church was in need. The meaning is similar to ptochos, but with the emphasis more on the severe lack of resources (need) than on a continuous state of poverty and destitution. Penichros is also a hapax legomenon (= occurring only 
lists categories of people who suffer, he tends to use $\pi \tau \omega \chi 0 \varsigma$ either heading the list (as in $4: 18 ; 6: 20 ; 14: 13,21$ ) or as climax (as in 7:1) in the end (Albertz 1983:199). This may create the impression that the term function as a sort of collective noun for all the disadvantaged (e.g. Busse 1978). Although the maimed, the blind and lepers were more often than not poor as well, and although poverty often led to sickness (as in Lazarus's case - cf. 16:20), one should be wary of reading semantic components of related dimensions of suffering into the term $\pi \tau \omega \chi 0 \varsigma$ (a fallacy that Barr 1969:218 designated as 'illegitimate totality transfer'). In the end it this robs the term of its economic connotation and allows the concept of the 'poor' to become spiritualised (as happend in Schmithals commentary 1980:62). Nothing in Luke's use of the term compels us to assign any meaning other than its basic economic reference of 'poor, destitute', even 'begging poor' ('bettelarm' - Rienecker 1970:137; cf. Louw \& Nida 1988:564; Bammel 1959:886), as will be demonstrated below.

- Luke's first use of the term occurs in his programmatic Nazareth episode (Lk

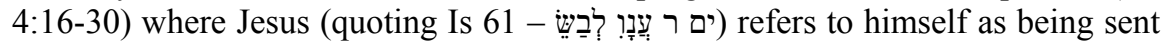
to 'evangelise the poor' (verse 18a). This reference is paralleled by the reference to the 'severe famine' in Elijah's day (4:25), clearly defining the poor as those that experience hunger during a famine. ${ }^{13}$ This also correlates with 'the hungry'

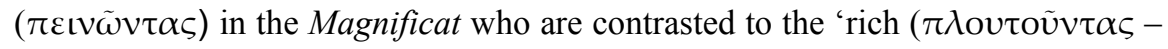
Lk 1:53). The term $\pi \tau \omega \chi 0$ os is not used there but implied as those who experience hunger.

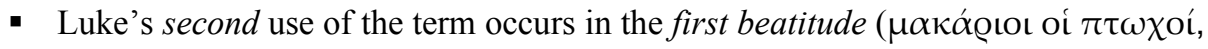
cf. 6:20b), which, unlike the $\pi \tau \omega \chi \chi i ̀ ~ \tau \tilde{\omega} \pi v \varepsilon v ́ \mu \alpha \tau \iota$ of Matthew 5:3, only permits a literal interpretation, especially in view of the second beatitude (oi $\pi \varepsilon \iota v \tilde{\omega} \nu \tau \varepsilon \varsigma$ $v \tilde{v} v$, cf. Lk 6:21//Mt 5:6) that stands in apposition to the first, semantically limiting it (hunger defines poverty as in 1:53).

- In Jesus answer to John the Baptist (Lk 7:22) the expression 'evangelise the poor' appears at the end of a list of suffering groups (the blind, the lame, lepers, the deaf, the dead). This comes from the Q-source in which original Palestinian context the term could also have referred to the anawim ('the poor') who idealised poverty, thereby giving it a religious meaning (cf. Scheffler 1993:50-51 and the remarks on the Psalms in par 1 above). However, nothing of this religious meaning can be detected in this passage, nor in Luke-Acts as a whole. To the contrary, for Luke the right attitude towards material possessions and the practice of charity has religious meaning - as will become clear below. The expression

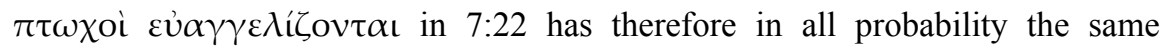

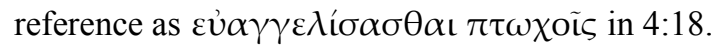

- Similar arguments apply for the next two uses of the term, namely Lk 14:13 (whom to invite to a meal) and 14:21 (the parable of the great banquet). In fact these two instances (that form part of Luke's Sondergut) provide even more convincing support for a literal meaning of Luke's concept of the poor: The meal and the banquet implies the materialistic motif of food and wealth which should

once) and has the same meaning as ptochos (cf. the reference to the poor widow in Lk 21:2). It is more likely to occur in poetic, literary contexts (cf. Louw \& Nida 1988:564).

13 Similarly Lk 4:18b is paralleled by the healing referred to in 4:27. Poverty and sickness are both separate dimensions of suffering to which Luke attends and which he does not mix up. 
be shared with 'the poor' who are unable to pay back (implying lack and extreme poverty - cf. 14:12-14).

- The parable of Lazarus and the rich man (Lk 16:19-30) provides a dramatic and vivid portrayal of what Luke had in mind when he employed the term $\pi \tau \omega \chi 0 \varsigma$ in Luke 16: 20 and 22. Both instances refer to Lazarus whose extreme poverty and physical suffering are in detail described in 16:20-21.

Apart from his skin disease ( $\varepsilon \dot{i} \lambda \kappa \omega \mu \varepsilon$ vo - 'full of sores'), Lazarus had to be placed or actually 'thrown' ( $\dot{\beta} \varepsilon \dot{\beta} \beta \lambda \eta \tau$ - sign of disrespect) at the rich man's gate, implying that he was also crippled. His poverty is defined by his physical desire to be fed by whatever fell ( $\tau \tilde{\omega} v \pi \imath \tau$ ó $v \tau \omega \nu)$ from the rich man's table. Jeremias (1970:183) defines these 'crumbs' (KJV) as pieces of bread that was dipped into the bowl and used to clean the hands before being dispensed under the table. His sores being licked by dogs added insult to injury. Lazarus is actually a case of poverty to the point of begging ( $\pi \tau \omega \chi 0 \varsigma$ in its basic literal sense) and he is clearly contrasted with an economically wealthy man (a $\pi \lambda$ ov́ $\sigma 10 \varsigma$ "dressed in purple and fine linen, living luxuriously" - 16:21b).

Furthermore, the parable functions in a context which deals with economic matters $(16: 1,5-7,9,13-14 a)$, namely the right use of money. Interpreting the $\mathrm{Q}$ tradition (God and Mammon cannot both be served, cf. Mt 6:22), Luke in 16:9-13 contends that, not serving money doesn't mean to discard it, but to serve God by means of it in terms of charity. Rightly used it should thus actually be befriended (16:9).

The parable of Dives and Lazarus emerges as the passage in Luke's gospel (perhaps even the whole New Testament) in which the plight of the poor receives the most intensive attention. Referring clearly to the begging poor with no evidence to the contrary (Lazarus's change of fate occurred in the next world) ${ }^{14}$ it should be assumed that he had the same reference in mind when he used the term elsewhere in the gospel. Actually, in terms of the to my mind sound exegetical principle of Lucas sui ipsius interpres est, ${ }^{15}$ the parable defines how the poor should be understood in the Luke-Acts.

- Luke edited his sources in such a way as to effect his economic pro-the-poor preference. In his version of Jesus' meeting with the rich ruler (18:22) he

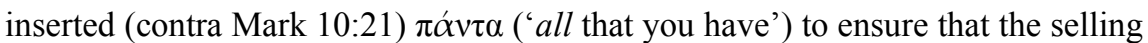
of goods in an economic sense is involved to ensure a treasure in heaven. This is further emphasised by Peter's response in 18:28 where $\tau \dot{\alpha}$ i $\delta 1 \alpha$ (our own things clearly defines Mark's $\pi \alpha ́ v \tau \alpha$ ('all things') in terms of possessions (Bammel 1959:904). Notice also the use of ' 1 iov in Acts 4:32: "No-one claimed that any of his possessions was his own ['iolov]".

- In Luke 21:3 (the poor widow) the term $\pi \varepsilon v \iota \chi \varrho \alpha$ is used which basically has the same reference as $\pi \tau \omega \chi 0 \varsigma$. The 'economic overtones' are clear in every verse in

14 The threat of hades actually testifies to the urgency with which Luke communicated his view. In psychological terms he actually attempts to condition his reader using negative reinforcement. For how he does this elsewhere (Luke 12:35-48), see Scheffler 1988.

15 Not to be confused with the unsound principle of sacra scriptura sui interpres which violates the unique views of different biblical books and traditions. 
this passage. The widow owned virtually nothing, but because she was prepared to give she is judged positively.

- In all the examples discussed thus far 'the poor' for Luke means the literal, materialistically poor. Furthermore, it is noteworthy that even if he omits the term when he renders Mark's Gospel, his very omission is due to a literal interpretation of $\pi \tau \omega \chi 0 \varsigma$. Luke's omission of the Marcan episode of the women with the ointment (Mk14:3-9) is most probably due to Jesus' seemingly negative attitude towards the poor in Mk 14:7 - Luke agreeing with Judas as it were (cf. however the discussion of Mk14:7 in footnote 5 above).

- Further support for the literal reference of the term in Luke can be found when one considers Luke's use of the term $\pi \lambda$ oú antonym of $\pi \tau \omega \chi \circ \varsigma$. Both these words are used (about 13 times) with an economic reference throughout the gospel (cf. 1:53; 6:24; 12:16; 14:12; $16: 1,19,21,22 ; 18: 23,25 ; 19: 2 ; 21: 1)$, except in one instance where the verb is

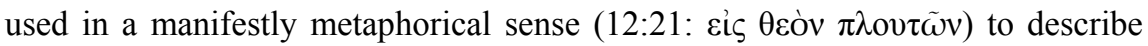
the rich fool's behavior of being not 'not rich towards God'. But even here Luke's view is underscored: his foolish behaviour consisted in selfishly relying on material possession and not giving to the begging poor as prescribed in 12:33: ("Sell your possessions and give to the poor. Provide purses for yourselves that will not wear out, a treasure in heaven that will not be exhausted, where no thief comes near and no moth destroys."). Thus for Luke's Jesus the doing of charity equals a 'treasure in heaven'.

The argument made here should be not be misunderstood. In Palestinian Judaism (cf. the anawim referred to above), as well as early Christianity (cf. the 'poor in spirit' of Mt 5:3) the term may have had more than just an economic reference. However, Luke (a Greek writer) used it literally as it was primarily understood in the Graeco-Roman world. In terms of Friesen's (2004) distinction (cf. table above) he had the bottom end of the economic ladder in mind: beggars, unattached widows, orphans, disabled, unskilled day labourers, prisoners and slaves).

Does this mean that Luke had only literal poverty in mind and not other dimensions of suffering? To the contrary: his gospel reflects an almost equal interest in the politically oppressed, the socially ostracised, the sick, the mentally ill and sinners (cf. Scheffler 1993:60-102). Concern for sinners (cf. e.g. the parable of the sinful woman of Lk 7, or the prodigal son in Lk 15) never caused him to use the concept of the poor metaphorically, thereby lessening the emphasis on the poor's literal economic suffering. This point is important whenever 'previously disadvantaged poor people' who have escaped their poverty tend to 'metaphorise' the concept for further gain or privileges. ${ }^{16}$

\section{Concern for the Poor without using the Term $\pi \tau \omega \chi o \varsigma$}

There are also other traditions where Luke communicated his perspective on poverty without employing the term $\pi \tau \omega \chi 0 \varsigma$. A brief look at these cases all testifies to the consistency of his stance.

16 As may happen in certain present-day contexts when 'affirmative action' is applied. 
- To the Magnificat where the rich are sent away empty-handed and the $\pi \varepsilon \omega v \tilde{\omega} \nu \tau \alpha \varsigma$ ('the hungry') are satisfied has already been referred. Hunger defines poverty.

- In his version of the beatitudes Luke again refers to 'the hungry' as those that are totally destitute. In Matthew both 'the poor' and 'the hungry' are both spiritualized ('the poor in spirit' and 'hunger and thirst for righteousness'). No trace of this in Luke: the poor are blessed and those that are hungry now (note the emphasis by the insertion of the word 'now') are satisfied (6:22).

- In Luke the Q-tradition of loving the enemy (Lk 6:27-36; contra Mt 5:38-48; $7: 12 \mathrm{a})$ the enemy functions as the poor to whom should be given when asked and lent without hoping to be repaid:

- Give to everyone who asks you, and if anyone takes what belongs to you, do not demand it back ... But love your enemies, do good to them, and lend to them without expecting to get anything back (Lk 6:30;35). ${ }^{17}$

- In Luke's version of another Q-tradition, namely the admonition to the Pharisees about inner morality as opposed to ritual morality (Lk 11:39; Mt 23:25-26), the references to the inside of the cup leads Luke to think of the food inside which

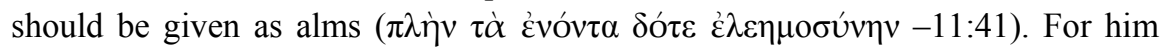
cleanliness does not merely constitute the removal of extortion and rapacity (as in Matthew 23:26), but the latter is spelt out in practical terms, namely the acts of almsgiving (to the begging poor). Charity seems to be the basis of all morality, since it purifies the doer (11:41b).

- Almsgiving (which implies the begging poor) in a similar fashion interprets the tradition of the heavenly treasure in which Luke in all probability amended Q. A comparison between his version and that of Matthew reveals his stance:

\begin{tabular}{|l|l|}
\hline \multicolumn{1}{|c|}{ Matthew 6:19-21 } & \multicolumn{1}{c|}{ Luke 12:33-34 } \\
Do not accumulate for yourselves & $\begin{array}{l}\text { Sell that ye have, and give alms; } \\
\text { treasures on earth, where moth and rust } \\
\text { provide yourselves bags which wax } \\
\text { destroy and where thieves break in and } \\
\text { steal. But accumulate for yourselves } \\
\text { treasures in heaven, where moth and rust } \\
\text { do not destroy, and thieves do not break } \\
\text { in and steal. For where your treasure is, } \\
\text { that faileth not, where no thief } \\
\text { approacheth, neither moth } \\
\text { corrupteth. For where your treasure } \\
\text { is, there will your heart be also. }\end{array}$ \\
\hline
\end{tabular}

Luke's version interprets the heavenly treasure not merely as refraining from accumulating earthly riches. He interprets the saying in practical terms ("sell your possessions and give alms", 12:33). This correlates with Jesus' advice to the rich ruler in Mk 10:21 ("Sell everything you have and give to the poor, and you will have a treasure in heaven") which Luke transmitted almost verbatim in Lk 18;22.

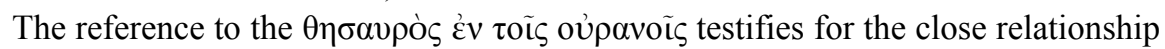
between the two traditions.

17 Lk 6:30 seems to imply a passive attitude even when one is robbed. The importance of Luke's 'economic interpretation' is underlined by Luke introducing the golden rule in this very context (6:31). According to

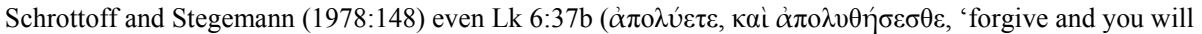
be forgiven') should be interpreted economically in the sense of release of debt since 'release' and 'set free' are the basic meaning of $\alpha \pi \mathrm{\alpha} \lambda \hat{v} \omega$ (cf. however, Marshall 1978:266 and numerous other places where the term is used with regard to forgiveness and release from sin - Scheffler 1993:97-99) 
- (6) John the Baptist's ethical preaching (Lk 3:10-14, cf. Scheffler 1990) also contains a reference to the extremely poor without employing the term $\pi \tau \omega \chi 0 \varsigma$. Those that have something (food and clothes) should give to those 'that have

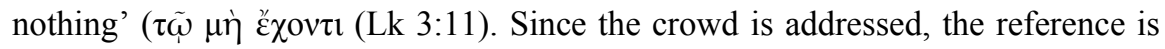
here not necessarily to the rich giving to the poor, but the relatively poor (who may still have something) who share with the poorest of the poor.

- (7) Lastly, the term $\pi \tau \omega \chi 0 \varsigma$ is also absent in Luke's vivid portrayal of the Good Samaritan's exemplary behaviour towards the half-dead man who fell amongst the robbers (Lk 10:30-37). Being robbed the latter a $\pi \tau \omega \chi 0 \varsigma$, and an essential part of the Samaritan's behaviour towards him functions on an economic level (cf. especially Lk 10:34-35).

\section{Luke's View of the Rich}

If it is established that Luke has a pro-poor stance, the question arises what attitude he reflects towards the rich. Does he unconditionally condemn the rich, as one may infer from the Magnificat (1:53) and the woe-saying of Lk 6:24? ${ }^{18}$ Or is there a role for the rich to play in his concern for the alleviation of the suffering of the poor?

One way of pursuing this question would be to analyse all the texts in Luke's gospel where reference towards the rich is made, as has been done above with regard to the poor. However, such an enterprise warrants a separate study which in all respects would not serve the purpose of this contribution focusing on the poor. Furthermore, I am of the opinion that a good insight of Luke's attitude towards the rich in their relation to poverty can be gleaned by looking at the parable of Lazarus and the rich man once more, but now in the context of Luke 16 as a whole. ${ }^{19}$

In order to obtain a fuller meaning of the Lazarus parable within the context of Luke's gospel, one should take into account Ellis's (1974:201) observation that the parable in 16:19-31 is 'double pronged' and, with the 'double pronged saying' in 16:1418, forms a single episode. In order to facilitate the discussion of Ellis's viewpoint, which also provides an explanation for the apparent strange insertion of the saying on divorce (Lk 16:18) in this context, Luke 16:14-18 in its parallelism to Luke 16:19-31 is schematised as follows:

18 These traditions (where the blessing of the poor is accompanied by the rejection of the rich (cf. also the parable of the rich fool and the Lazarus and the rich man) are designated by Horn (1980:168-188) as 'ebionite' traditions.

19 That Lk 16:1-31 should be interpreted as a one literary unit is recognised by nearly all commentators under the rubric "the correct use of earthly possessions", e.g. Klostermann [1929] 1975:161-170; Rengstorf 1974:187-196; Grundmann 1974:315-330; Schweizer 1982:167-174 (including 17:1-10); Wiefel 1988:290297; Klein 2006:534-556; Wolter 2007:542-563. Even Ellis (1974:198-206) who distinguishes two units in chapter 16 and Fitzmyer (1985:1094-1136) distinguishing six, also discuss the close relationship between these units at an editorial level. 


\begin{tabular}{|l|l|}
\hline \multicolumn{1}{|c|}{ The Parable of Lazarus Elucidating the Jesus-Sayings of Luke 16:14-18 } \\
\hline \multicolumn{1}{|c|}{ Lk 16-15 } \\
$\begin{array}{l}\text { Addressing money loving Pharisees: } \\
\text { 'What is highly esteemed among men is } \\
\text { an abomination in the sight of God' }\end{array}$ & $\begin{array}{l}\text { Lazarus in Abraham's bosom (16:22a }= \\
\text { Happy are you poor, 6:20) } \\
\text { The rich man in hell (16:22b-26 = Woe } \\
\text { unto you that are rich, 6:24) }\end{array}$ \\
\hline $\begin{array}{l}\text { Lk 16:16-18 } \\
\text { The continuing validity of the law. }\end{array}$ & $\begin{array}{l}\text { The need to listen to Moses and the } \\
\text { prophets }\end{array}$ \\
\hline
\end{tabular}

As far as the first part of the parable (16:19-26) is concerned, the narrative structure can actually be defined in terms of the sayings "Blessed are you poor, for yours is the kingdom of God" and "Woe to you that are rich" of Luke 6:20 and 24. Lazarus's unhappy fate is reversed, while the fate of the rich man changes for the worse (16:22-23). The reversal of fortunes is portrayed in such vehement (16:23-24b) and final terms $(16: 26)$ that the reader may initially well be puzzled by the hell-fire torments of the rich man, since the reason for his punishment is not explicitly mentioned. However, the explanation for Luke's apparent attitude of "woe to you that are rich" is to be found in the second part of the parable (16:27-31), as well as the parable's position in the context of Luke 16.

The second part of the parable (16:27-31) provides some explanation for the reversal of fortunes: when the rich man began to plead for his five brothers, Abraham refers him to 'Moses and the Prophets'. His remark 'let them listen to them' (16:29) implies that the rich man should attribute his suffering to his remissness in obeying Scripture. We are not told, however, in what way the rich man has failed to obey Scripture.

Luke 16 begins by Jesus narrating the parable of the shrewd manager (16:1-8) who through the (unjust) use of money assured for himself security after losing his job. In his commentary on the parable (16:9-13), Jesus explains why he praised the steward and urges his followers to 'make friends' by means of earthly wealth (= the unrighteous mammon, 16:9) and to be "faithful in the unrighteous mammon" (16:11). Since from verse 13 it is clear that faithfulness here implies readiness to serve God, "making friends with mammon" does not mean serving mammon by a relentless gathering of more riches (cf. the rich fool), but using riches as a means of serving God.

Luke 16:14-18 contains the Pharisees negative reaction to Jesus' interpretation of the parable and Jesus' response to their reaction. The Lucan Pharisees ${ }^{20}$ (who loved money) could not stomach Jesus' words advocating the unselfish use of money and scoffed at him (16:14). Jesus' response in 16:15-18 is, like the Lazarus parable (16:19-26) 'double pronged' (cf. Ellis 1974:201 and the schematization above).

Firstly, in verse 15 Jesus refers the Pharisees to the values that matter to God: these values are contrary to human values, in fact human values are an abomination $(\beta \delta \varepsilon \dot{\varepsilon} v \gamma \mu \alpha)$ to God. The first part of the parable of Lazarus and the rich man (especially $16: 22-26)$ is a vivid illustration of this basic principle.

20 The 'Lucan Pharisees' should not be confused with the actual Pharisees of Jesus' day. The latter were actually not rich, but since they became the antagonists in the Jesus' story, Luke used them to represent the antagonists in his story, namely the rich. Hence the redactional note 'who loved money'. 
Secondly, in verses 16-18, Jesus refers to the Law and the Prophets, which are still binding (even more stringently as far as adultery is concerned - cf. 16:18) and are not abrogated by the preaching of the kingdom of God (16:16-18). Jesus' remarks in 16:1618 correspond with the second part of the parable (16:17-31): the rich man should have listened to Moses and the prophets.

Within the context of chapter 16 as a whole it becomes clear that the rich man served mammon and not God (16:13b). Like the Pharisees he was a 'lover of money'

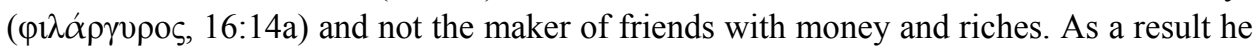
was not received 'into the eternal habitations' $(16: 9 \mathrm{~b})$ but had to endure the anguish of Hades (16:23-25). The woe of 6:24b applied to him.

The situation of the parable forces the Lucan reader to ponder those sections of Moses and the Prophets that the rich man (and the Pharisees who scoffed at Jesus) overlooked. The clues to the reader are the demand to serve by means of mammon and the situation in the parable in which the rich man disobeyed. Faced with the poor man Lazarus at his gate, he should have served him (and thereby also God) with his money. Deuteronomy 15:1-11 is perhaps the section in the Torah which most prominently focuses on the plight of the poor and especially verse 7-11 recalls the situation of the parable:

If there is among you a poor man, one of your brethren, in any of your towns within your land which Yahweh your God gives you, you shall not harden your heart or shut your hand against your poor brother, but you shall open your hand to him... You shall give to him freely, and your heart shall not be grudging when you give to him; because for this Yahweh your God will bless you in all your work and in all that you undertake. For the poor will never cease out of the land; therefore I command you, You shall open wide your hand to your brother, to the needy and to the poor, in the land (RSV).

That the rich man did not heed these words from 'Moses and the Prophets' is evident from Lazarus's desire to satisfy his hunger with what fell from the rich man's table (16:21). He was rejected not for his riches per se (according to Dt 14:10 he could as a wealthy person have been blessed in all his undertakings), but because he did not show mercy by giving to the poor.

This idea correlates with what we read elsewhere in the gospel with regard to the rich ruler (18:18-30), and especially the Sondergut episode of Zacchaeus, the toll-collector

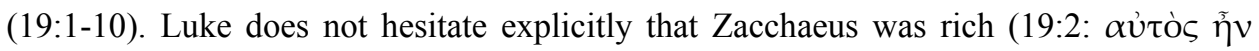

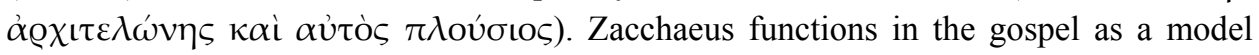
how a rich man should behave: because he was prepared to give half of his possessions to the poor, he was saved and (like Lazarus in16:23) was called a son of Abraham (19:9; cf. also Schrottroff \& Stegemann 1978:137-140).

Degenhardt's contention (1965:133) that the whole of Luke 16 forms a unit and is '.. ein "ethisches Kompendium, das dem christlichen Amtsträger für seine ethische Unterweisung material in die hand gibt", seems to be supported by the above analysis. The injunction to make friends by means of mammon (16:9) is a call to serve God (16:13b), being a call to charity ('Mahnung zur Wohltätigkeit' (1965:120-125). The addressees, however, should probably (contra Degenhardt) not be limited to the Christian clergy of Luke's day, but include especially the rich Christians to whom Luke's gospel in all likelihood is directed (Van Tilborg 1988:212). 


\section{Renunciation of Possessions and Charity}

In view of the fact that Luke usually emphasises the immediate relief of suffering (cf. his use of 'today' in $2: 12 ; 4: 21 ; 13: 22 ; 19: 5,9 ; 23: 43$, 'immediately' in 4:39; 5:25; $8: 44,47,55 ; 13: 13 ; 18: 43$; Ac $3: 7$ and 'now' in $1: 48 ; 2: 29 ; 11: 20 ; 17: 21)$, the eschatological nature of the promise of the kingdom to the poor in $6: 20 \mathrm{~b}$ (cf. also Lazarus's salvation which only occurred in the hereafter) poses a problem. Is the ultimate liberation from poverty meant for the afterlife, while the poor's plight in this life continues? Should Christians (by selling their possessions) impoverish themselves in this life in view of the 'treasure of heaven', as Lk 12:33 seems to suggest?

Luke's concern for the poor seems to be closely related to his view of personal possessions and charity. Jesus' followers are told to do away with possessions and give to the poor. An austere lifestyle seems to be advocated. There indeed exists a dialectical tension in the Lucan perspective with regard to the renunciation of passions and practicing charity. However, this tension expresses the essence of Luke's stance which provides an answer to the abovementioned eschatological problem. In order to highlight this, some traditions already discussed will again be referred to.

In our discussion of the parable of Lazarus and the rich man (cf. par 3.1 above) it was noted that although Lazarus's ultimate salvation was eschatological, in the context of Luke 16 the parable functioned as encouragement to the Pharisees (as lovers of money) to practice charity towards the extremely poor (like Lazarus) in this life. ${ }^{21}$

In John the Baptist ethical preaching (in which Luke tones down John's proclamation of judgment, as presented to him by Q (cf. the insertion of 3:6,10-14,18, cf. Conzelmann 1964) the haves (even if a little) are prompted to give to the have-nots (the begging poor). This correlates with Luke's presentation of the early church as a sharing community (cf. Ac 2:44-47). That the church in Jerusalem was poor is suggested by the collection taken for them by the Hellenistic churches (Rm 15:26; 2 Cor 8:4) where the term $\pi \tau \omega \chi 0 \varsigma$ is employed to typify them (cf. Joubert 2000). In Jerusalem (Luke's ideal) it was not just a case of the rich giving to the poor, but of Christians, rich and poor alike, sharing.

For Luke, renunciation of possessions (Besitzverzicht) and charity go hand in hand. Sublte emendations to his sources emphasise this notion. It was noted above that in Luke's emendation of Q (11:39-4) almsgiving to the poor constitutes the basis of a purified life. Strict Jewish purification laws are criticised, regarded as unnecessary and replaced by an ethic of charity. However, the ethic of charity is accompanied by a sober lifestyle, probably not because of a value which the latter would have in itself (there exist enough passages in the gospel where life is celebrated), but since in Luke's view it promoted giving to the poor and thereby served the amelioration of their suffering. Interestingly Luke deleted all possible references to the fact that Jesus owned a house (cf. Mk 2:1-2 in Lk 5:17; Mk 2:15 in Lk 5:29; Mk 9:33 in Lk 9:46; cf. also Lk 24:12). Not asceticism, but austerity is clearly advocated in Luke's unique tradition of Jesus' answer to the man who wanted his brother to share his inheritance (12:13-15). The man is expressly warned against greed for "a man's life does not consist in the abundance of his possessions" (12:15). The Lucan Jesus immediately drives his message home by relating the parable of the rich fool advocating 'richness toward God' (12:21) instead of the accumulation of possessions. By transmitting the Q-tradition about earthly anxieties (12:22-31; Mt 6:25-33) directly after the parable of the rich fool, Luke almost seems to

21 For a detailed analysis of Luke 16 as a whole, see Scheffler 1978. 
imply that one should not worry even about the commodities needed for daily living, one's sole concern being to seek God's kingdom and secure a heavenly treasure. However, it was noted above in the rendition of the latter tradition (12:33-34; Mt 6:1921 ) that the practice of charity (providing the poor with the commodities needed for daily living) is the way to secure the heavenly treasure. The latter can therefore not be viewed solely in eschatological terms.

It can be concluded that for Luke 'the poor' (whether expressed by the term $\pi \tau \omega \chi 0 \varsigma$ or in other ways) are not a spiritualised concept but refers to real people living in this world, people who are not only eschatologically blessed (6:20) but whose this-worldly needs also have to be satisfied. The fact that people are called to beware of greed $(12: 15$; cf. also $3: 14)$ while simultaneously doing charity is an important feature of Lucan soteriology. Liberation of the poor will come about not just through God's ultimate action, but especially through human pity and sharing (which equals richness towards God, the receiving of his kingdom and heavenly treasure). The injunctions to renounce possessions (Besitzverszicht, Armutsforderung) and practice charity (Wohltätigkeitsparänese) are juxtaposed dialectically and should not be contrasted (contra Horn 1983:186-188). The main thrust of Luke's argument is that the lot of the poor should be ameliorated.

In what follows attention will briefly be paid to the question of how Luke's views were appropriated in Christianity and some hermeneutical remarks will be made in view of the poverty that still confronts us in our contemporary world.

\section{Appropriations of Luke's View of the Poor throughout History \\ Individual Appropriation}

Throughout history individual Christians (and even admirers) of the Lucan story have attempted in various ways to respond positively to Luke's view on poverty alleviation. These appropriations are so numerous that all the tales can never be told. Especially in a world where most people struggle to survive, parables such as the Good Samaritan, Lazarus and the rich man and the rich fool had inspired individual people to be cautious of a too affluent life style and to share with the poor. St Francis of Assisi started a movement in the $12^{\text {th }}$ century that led to the establishment of the Franciscan order in the Roman Catholic Church. Mother Theresa of Albania's very personal and individual enterprise in Calcutta led to her winning the Nobel Peace Prize and obtaining a state funeral in India (where the Christian religion is in a minority). These are well-known figures. Since all Christians are addressed by the Jesus story there exist many untold stories of individual charity to the poor that could never be measured, but should never be underestimated. ${ }^{22}$

22 Unfortunately the trend is also wide-spread in Christianity that faith has mainly to do with individual salvation in view of eternal life and that God blesses saved Christians with material prosperity in this life. Charity and social engagement are in some Christian circles scoffed at as being expressions of 'social gospel' and 'humanism'. A present-day example of this type of theology are the remarks made by a leading theologian in a popular religious article in the Afrikaans newspaper Beeld. Recognising the positive value of Jesus' teaching in and for the present world, he concluded that these values are not the most important aspect of Christianity because one 'cannot build eternal life upon it'. (Full bibliographical details withheld, the purpose not being to expose the author.) 


\section{Monastic Life}

It was observed above that in Luke 12:33 Jesus warns his disciples against covetousness and to sell their possessions and give to the poor in order to obtain a treasure in heaven. In Acts 2 the early Jerusalem church is depicted as to have done just that. The effectiveness of this 'Liebeskommunismus' has often been questioned. It has been suggested that it caused ultimate poverty in the Jerusalem church. It also does not seem from the rest of the New Testament writings that such practices have become universal. In Paul's letters it is reported that churches in Asia Minor supported the church in Jerusalem by sending a collection to them (2 Cor 8-9; cf. Joubert 2000). Although charity is implied, it does not entail a total sharing of goods. However, taking as a point of departure that the renunciation of possessions advocated in Luke's gospel was rather voluntary than compulsory, it has been maintained in Roman Catholicism that Luke's view has throughout history been internalised in monasteries where monks or nuns live without personal possessions. In one of the first full-fledged studies on poverty in Luke's gospel, Degenhardt ${ }^{23}$ (1965) argued that texts such as Lk 9:1-6; 12:13-34; 14:7-35 and 16:1-31 are addressed to the disciples and therefore primarily aimed not at the lay community, but at the clergy of Luke's day. Although this view can be questioned (cf. the role of ordinary women in 8:1-3 and the rich who were also addressed, cf. the Pharisees in Lk 16) the communal life in monasteries and the latter's endeavour to do charity to the poor cannot be downplayed.

\section{The Communism advocated by Karl Marx}

It has often been argued that Karl Marx made use of the Lucan text for his views on communism. Luke is interpreted as striving for a classless society where nobody would be poor or rich. Acts 2:43-47 and 4:32-37 come to mind. The early Christians would have sold their property and possessions and distributed their money among all, according to what each needed. The adage, "from each according to his ability, to each according to his need" is said to be based on Luke 12:33, Acts 2 and 4,11:29. It is most likely that Marx's eventual atheism obscured the fact that he obtained the idea of communism from the Lucan writings.

\section{Liberation Theology}

Since 1970 Luke's Gospel has also featured prominently in liberation theology. In situations of political oppression and exploitation God is viewed as having a preferential option for the poor. Together with the exodus tradition the text that features most prominently in the New Testament is Luk4:18,19a (quotes from Isaiah 61):

The Spirit of the Lord is upon me

Because he has anointed me

To preach good news to the poor

He has sent me

To proclaim release to the captives

And recovering of sight to the blind

To set at liberty those that are oppressed

To proclaim the acceptable year of the Lord.

23 A Roman Catholic priest who later became bishop of Paderborn, Germany. 
The phrase ("to set at liberty those that are oppressed") is usually singled out by liberation theologians. In the appropriation of the Lucan text it is often read at face value $^{24}$ and applied directly to contexts without taking Luke's original context, nor the ancient economic practices and stratifications into account. The poor are often interpreted to be poor as the result of the oppression they suffer at the hand political powers. Not denying the political dimension (cf. Scheffler 1993:75-83), in the context of Luke-Acts liberation is, however, not confined to political liberation but entails various dimensions. ${ }^{25}$ Luke 4:18 communicates that Jesus is the Messiah because he cares and acts to the advantage of all those who suffer. Neither political nor spiritual suffering is excluded - on the contrary, both, as well as any kind of suffering, are included. ${ }^{26}$ Reading Luke in its Roman context has its point of departure from those that really suffer, and not exclusively from those who search for political emancipation.

\section{Conlusion: Some Hermeneutical Considerations}

- Living in a post-modern world, present-day readers of the Lucan text involuntarily carry their own contexts with them, and these contexts (with all their individual and social histories) not only influence the reading process but are reciprocally influenced by the reading process. Extreme poverty (to the point of begging) was a major concern for Luke and it cannot otherwise but also be our concern today where about one billion people (one sixth of the world population) share the same fate. The major direct contribution to modern thinking of Luke's gospel is to make us aware what we (in our striving for a contented life) tend to ignore that millions of people starve to death daily.

- It emerges clearly from Luke's gospel that poverty, without being relativised or spiritualised, should be viewed in its interconnectedness with other forms of human suffering or marginalisation, such as sickness, mental disturbance and social ostracism (cf. Luke's positive attitude to 'rich' toll-collectors, shepherds, soldiers, prostitutes, 'sinners', women and children). Any association or identifying with the poor for the sake of self-interested political gain which in the end does not benefit the real poor, should be exposed. The myth should also be expelled that people whose material needs are met, are incapable of suffering. Although there more often than not exists a correlation between wealth and health, sickness and poverty, ills such as cancer and AIDS know no class distinction.

- Living in a globalised world has contributed greatly to the creation of tremendous wealth, to such an extent that if it would be distributed equally, all poverty could be eradicated. Of course such a mere distribution could compromise the sustainability of the wealth of the world. However, Luke's gospel reminds us that an unlimited striving for wealth at the cost of the poor goes against the grain of human dignity. A balance should be found between sustainable wealth creation

24 The term tethrausmenous is mostly translated into English as 'oppressed', but the reference should actually be understood in terms of Acts 10:37-38 where Luke in his own words summarises Jesus' ministry. The parallel expression there is katadunasteuomenous (by the devil), referring to demon possession.

25 Six dimensions can be distinguished (economic, social, political, physical, psychological and spiritual), cf. Scheffler 1993:60-102.

26 For an attempt to read Luke's Gospel from the perspective of liberation theology taking its literary and ancient context into consideration, see Scheffler 1991, the purpose being to deepen the concept of liberation, not to criticise it. 
and the eradication of poverty. For this no supernatural miracle is required, but correct human choices which combine the apparently contradictory values of clinical economics and compassion for the poor, as argued Sachs (2005).

- The recent economic crisis in the Western world has also clearly shown that 'naked' capitalism is not automatically the correct economic system just because communism failed. The initial success of Kibbutzim in Israel also indicates that in certain contexts (where people have virtually nothing but share the little they have) can be helpful in getting a country's economy going. In Luke's gospel both the renunciation of possessions and charity are presented as options for the alleviation of the suffering of the poor. These two modes of economic behaviour should therefore not be seen as mutually exclusive, but can be applied depending on how situations of poverty present themselves. From the Lucan perspective which takes the suffering of the poor as the point of departure, it stands to reason that the Christian reader inspired by Lucan thought won't choose between poverty eradication by collective structures (e.g. the church and state) and endeavours by the individual, but advocate both.

- Last but not least, it should be mentioned that Luke's intense interest in the suffering of the poor is not motivated by any kind of asceticism (which the motif of renunciation of possessions may seem to suggest), but by the motif of joy. For that reason the gospel for the poor spells good news (Lk 4:18). Jesus' (who was no ascetic, cf. QLk 7:37) coming is interpreted as a wedding feast (Lk 5:33-34); festive meals should be shared with the poor (Lk 14), and in Luke 15 the father exuberantly celebrates the homecoming of his prodigal and impoverished child.

\section{BIBLIOGRAPHY}

Albertz, R 1983. Die Antrittspredigt Jesu im Lukasevangelium auf ihrem altestamentlichen Hintergrund. ZNW 74,182-206.

Barr, J 1969. The semantics of biblical language. London: Oxford University Press.

Bauckham, R (ed.) 1998. The gospels for all nations: Rethinking the gospel audiences. Grand Rapids: Eerdmans.

Bammel, E 1959. s v $\pi \tau \omega \chi 0 \varsigma$ etc. ThWNT.

Berges, U 2000. Armoede en haar bestrijding in de wetten van het OudeTestament. Tijdschrift voor Theologie, 40(3), 227-250.

Bosman, HL, Gous, IGP, Spangenberg, IJJ (eds.) 1991. Plutocrats and paupers: Wealth and poverty in the Old Testament. Pretoria: Van Schaik.

Botha, PJJ 1988. God, emperor worship and society: Contemporary experiences in the book of Revelation. Neotestamentica 22, 87-102.

Bourmer, A, Reincke, M \& Strüber, R 2002. Rom. Ostfildern: Karl Baedeker.

Braulik, G 1986. Das Deuteronomium und die Menschenrechte. ThQ 166/1, 8-24.

Busse, U 1978. Das Nazareth Manifest-Jesu: eine Einführung in das lukanische Jesusbild nach Lk 4, 16-30. Stuttgart: Katholisches Bibelwerk.

Claridge, A 2010. Rome: An Oxford archaeological guide. 2nd ed. Oxford: Oxford University Press. 
Conzelmann, H 1964. Die Mitte der Zeit: Studien zur Theologie des Lukas. 5.Aufl. Tübingen.

Constable, N 2003. Historical atlas of ancient Rome. New York: Checkmark Books.

Degenhardt, H-J 1965. Lukas - Evangelist der Armen: Besitz und Besitzverzicht in den lukanischen Schriften. Stuttgart: Katholisches Bibelwerk.

Ellis, EE 1974. The Gospel of Luke. London: Oliphants.

Farisani, EB 2005. A sociological reading of the confrontation between Ahab and Elijah in 1 Kings 21:1-29. OTE 18(1), 47-60.

Fitzmyer, JA 1985. The Gospel according to Luke X-XXIV: Introduction, translation, and notes. New York: Doubleday.

Friesen, SJ 2004. Poverty in Pauline studies: Beyond the so-called new consensus. JSNT 26(3), 323-361

Groenewald, A 2003. Psalm 69: Its Structure, Redaction and Composition. Münster: Lit Verlag.

Grundmann, W 1974. Das Evangelium nach Lukas. 7.Aufl. Berlin: Evangelische Verlaganstalt.

Gunneweg, AH 1987. Nehemia. Gütersloh: Gerd Mohn.

Guthrie, D 1970. New Testament introduction. 3rd ed. London: Tyndale Press.

Horn, FW 1983. Glaube und Handeln in der Theologie des Lukas. Göttingen: Vandenhoeck.

Jeremias, J 1970. Die Gleichnisreden Jesu. 8.Aufl. Göttingen: Vandenhoeck \& Ruprecht.

Jeremias, J 1971. Neutestamentliche Theologie: erster Teil; die Verkündigung Jesu. Gütersloh: Gerd Mohn.

Jeremias, J 1974. Jerusalem in the time of Jesus: An investigation into the economic and social condtions during the New Testament period. London: SCM.

Joubert, S 2000. Paul as benefactor: Reciprocity, strategy and theological reflection in Paul's collection. Tübingen: Mohr Siebeck.

Klein, H 2006. Das Lukasevangelium. 10.Aufl. Göttingen: Vandenhoeck \& Ruprecht (KEK I/3).

Klostermann, E [1929] 1975. Das Lukaseveangelium. 3.Aufl. Tübingen: Mohr.

Kraus, H-J 1979. Theologie der Psalmen. Neukircken: Neukirchener Verlag.

Louw, JP \& Nida, EA 1988. Greek-English lexicon of the New Testament based on semantic domains: Volume 1: Introduction \& domains. New York: UBS.

Lohfink, N 1992-1994. Die Armen in den Psalmen. Teil I \& II. (Vorlesungsmanuskript Wintersemester). Frankfurt am Main: Hochschule Sankt Georgen.

Longenecker, BW 2009. Exposing the economic middle: A revised economy scale for the study of early urban Christianity. JSNT, 31(3), 243-278.

Marshall, IH 1978. The Gospel of Luke: a commentary on the Greek text. Exeter: Paternoster.

Quennell, P 1971. The Colosseum. New York: Newsweek.

Rahlfs, A 1892. 'Ani und 'Anaw in den Psalmen. Göttingen: Dieterichsche Verlagsbuchhandlung.

Rengstorf, KH [1937] 1974. Das Lukasevengelium. Göttingen: Vandenhoeck \& Ruprecht. 
Rienecker, F 1970. Sprachlicher Schlüssel zum Griechischen Neuen Testament. Giesen: Brunnen-Verlag.

Rudolph, W 1949. Ezra und Nehemia samt 3. Ezra. Tübingen: Mohr (HAT 20).

Sachs, JD 2005. The end of Poverty: How we can make it happen in our lifetime. London: Penguin

Scheffler, EH 1978. Die noodlydende in die Lukaanse reisberig. Skripsie vir Nagraadse Diploma in Teologie, Universiteit van Pretoria.

Scheffler, EH 1988. A psychological reading of Luke 12:35-48. Neotestamentica, 22, 355-371.

Scheffler, EH 1990. The social ethics of the Lucan Baptist. Neotestamentica, 23, 252-267.

Scheffler, EH 1991. Reading Luke from the perspective of liberation theology, in Hartin, PJ \& Petzer, JH (eds.), Text and interpretation: New approaches in the criticism of the New Testament. Leiden: Brill.

Scheffler, EH 1993. Suffering in Luke's Gospel. Zürich: Theologischer Verlag.

Scheffler, EH 2005. Deuteronomy 15:1-18 and poverty in (South) Africa, in Otto, E \& Le Roux JH (eds.), A critical study of the Pentateuch: An encounter between Europe and Africa, 97-115. Münster: Lit Verlag.

Scheffler, EH 2006. Compassionate action: living according to Luke's gospel, in Van der Watt, JG (ed.), Identity, ethics, and ethos in the New Testament, 77-106. Berlin: De Gruyter (BZNW 141).

Scheffler, EH 2009. Jesus the Jew for today: A hermeneutical exercise. Acta Patristica et Byzantina 20, 217-241.

Scheffler, EH 2010. Pro the poor in the Pentateuch, in Scheffler, EH \& van Heerden, S (eds.), The Bible and the eradication of poverty: Tutorial letter OTS2604/501/3/2010. Pretoria: Unisa.

Scheffler, EH 2011. Pleading poverty (or identifying with the poor for selfish reasons): On the ideology of Psalm 109. OTE 24 (1), 192-207.

Scheffler, EH \& Van Heerden, SW (eds.) 2010. The Bible and the eradication of poverty: Tutorial Letter 501/OTS2604. Pretoria: Unisa.

Scheidel, W 2006. Stratification, deprivation and quality life, in Atkins, M, Osborne, R (eds.), Poverty in the Roman world, 40-59. Cambridge: Cambridge University Press.

Schmithals, W 1975. Lukas - Evangelist der Armen, in Theologia Viatorum XII: 1973/1974: Jahrbuch der kirchliche Hochschule Berlin, 153-167, hrsg von Dr Michel. Berlin: Die Spur.

Schmithals, W 1980. Das Evangelium nach Lukas. Zürich: Theologischer Verlag.

Schmithals, W 1985. Einleitung in die drei ersten Evangelien. Berlin: De Gruyter.

Schnelle, U 2007a. Einleitung in das Neue Testament. 6.Aufl.Göttingen: Vandenhoeck \& Ruprecht.

Schnelle, U 2007b. Theologie des Neuen Testaments. Göttingen: Vandenhoeck \& Ruprecht.

Schrottoff, L \& Stegemann, W 1978. Jesus von Nazareth - Hoffnung der Armen. Stuttgart: Kohlhammer Verlag. 
Schweizer, E 1975. Das Evangelium nach Lukas. Göttingen: Vandenhoeck \& Ruprecht.

Spangenberg, IJ 2010. Poverty in Israel's wisdom literature, in Scheffler \& Van Heerden (eds.) 2010:101-120

Usue, EO 2010. Nehemiah's regio-ethical wisdom in resolving an economic crisis in the post-exilic Judah (Neh 5:1-19): A lesson to be learned in Africa. Paper presented at OTSSA's 53rd annual congress, 15-17 Sept 2010. North-West University's Vaal Triangle Campus.

Van Heerden SW 1991. Prophets and profiteers: Prophetic perspectives on wealth and poverty, in Bosman, HL, Gous, IGP, Spangenberg, IJJ, (eds.), Plutocrats and Paupers: Wealth and poverty in the Old Testament, 206-227. Pretoria: Van Schaik.

Van Heerden, SW 2010. Poverty and prophetic critique, in Scheffler \& van Heerden 2010:73-90.

Van Tilborg, S 1988. Luke 12:35-48; an interpretation from the ideology of the text. Neotestamentica 22, 205-215.

Whittaker, CR 1993. Land, city and trade in the Roman Empire. Aldershot: Variorum Ashgate.

Wiefel, W 1988. Das Evangelium nach Lukas. Berlin: Evangelische Verlaganstalt. Wolter, M 1988. Das Lukaseveangelium. Tübingen: Mohr Siebeck (HNT 5). 